\title{
DEMOGRAFSKI POTENCIAL HRIBOVSKIH KMETIJ NA DRAVSKEM POHORJU
}

\author{
Boštjan Kerbler - Kefo \\ Urbanistični inštitut RS, Trnovski pristan 2, SI - 1000 Ljubljana, Slovenija \\ e-mail: bostjan.kerbler@guest.arnes.si
}

Izvirni znanstveni članek

COBISS 1.01

\begin{abstract}
Izvleček
V prispevku je prikazan in ovrednoten demografski potencial hribovskih kmetijah na Dravskem Pohorju, in sicer so predstavljene značilnosti socio-ekonomske strukture, depopulacije in deagrarizacije, demografske vitalnosti, delovne storilnosti in nasledstvene kontinuitete hribovskih kmetij. Rezultati kažejo, da je zaradi stalnega odseljevanja predvsem mladega prebivalstva oslabljena demografska vitalnost, številne kmetije pa tudi nimajo zagotovljene ustrezne nasledstvene kontinuitete.
\end{abstract}

Ključne besede: agrarna geografija, podeželje, hribovske kmetije, Dravsko Pohorje, demografski potencial

\section{DEMOGRAPHIC POTENTIAL OF MOUNTAIN FARMS ON DRAVSKO POHORJE}

\begin{abstract}
In the article is represented and evaluated the demographic potential of mountain farms on Dravsko Pohorje. The characteristics of socio-economic structure, depopulation, deagrarization, demographic vitality, productiveness, and succession continuity of mountain farms are described. The results indicate that demographic vitality is weakened due to permanent emigration of young population, as well as succession continuity on many farms is not assured.
\end{abstract}

Key words: agrarian geography, rural areas, mountain farms, Dravsko Pohorje, demographic potential 


\section{UVOD}

V hribovitem svetu je osnovna sila za spreminjanje kulturne pokrajine demografski potencial hribovskih kmetij (Natek 1989, 292), saj lahko spreminja proizvodne, socialne, družbene in druge pokrajinske vrednote in z njimi vred vpliva na transformacijo celotne pokrajine.

Demografske potenciale smo podrobneje preučili na kmetijah na Dravskem Pohorju - v pokrajini, ki je značilna po poselitvi s hribovskimi kmetijami in se po Zgoniku (1977) razteza po severnem delu Pohorja, od njegovega razvodnega grebena do doline reke Drave. Anketiranje smo izvedli leta 2001 v občini Ribnica na Pohorju, v kateri je naselje Ribnica na Pohorju manjše gravitacijsko središče za obsežno agrarno zaledje. Vanj smo vključili vsa kmetijska gospodarstva na preučevanem območju, torej 100 enot, rezultate analize pa predstavljamo za 87 t. i. evropsko primerljivih kmetij - kmetij, ki ustrezajo velikostnim merilom Evropske unije.

\section{SOCIO-EKONOMSKA STRUKTURA HRIBOVSKIH KMETIJ}

Na preučevanem območju imajo najvišji delež čiste kmetije, in sicer jih je $30 \%$, kar je več, kot je znašalo slovensko povprečje leta 1991 (21,3 \%) oziroma skoraj polovico več, kot ugotavljajo za leto 2000 Udovč in drugi (2006), in sicer 17,3 \% (podatek zaradi drugačne metodologije izračuna socio-ekonomskih tipov ni neposredno primerljiv.). Kriterije za opredelitev socio-ekonomskih tipov hribovskih kmetij na območju preučevanja smo povzeli po Kovačiču $(1983 ; 1996)$.

Slika 1: Socio-ekonomska struktura kmetijskih gospodarstev v občini Ribnica na Pohorju.

Figure 1: Socio-economic structure of farms in municipality Ribnica na Pohorju.

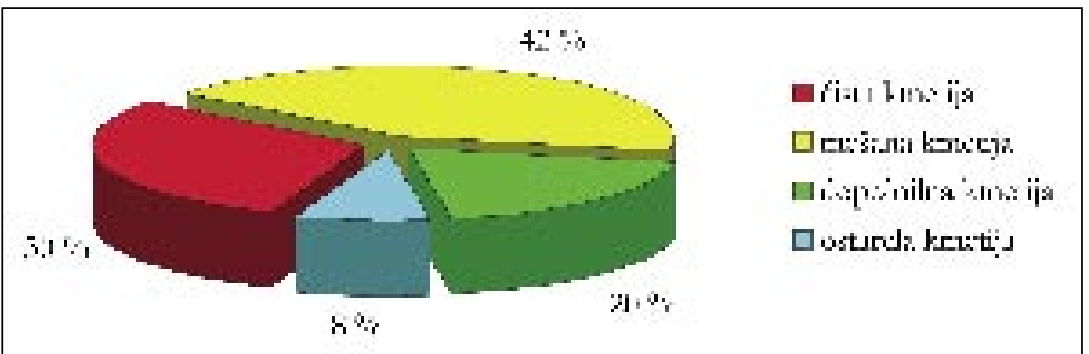

Zaradi visokega deleža čistih kmetijskih gospodarstev sodi po Kovačiču (1997) območje preučevanja med območja z nadpovprečno stopnjo profesionalizacije kmetijstva, kar pomeni, da predstavlja kmetijstvo pomembnemu delu kmečkega prebivalstva edini ali pretežni vir dohodkov. 


\section{DEMOGRAFSKE ZNAČILNOSTI HRIBOVSKIH KMETIJ}

\section{I Depopulacija in deagrarizacija}

$\mathrm{Z}$ razvojem sekundarnih, terciarnih in kvartarnih dejavnosti se je podobno kot drugje $\mathrm{v}$ Sloveniji tudi na območju preučevanja po drugi svetovni vojni pospešil proces deagrarizacije. Čeprav se je zmanjšal delež zaposlenih v primarnem sektorju, pa v primerjavi z nekaterimi drugimi hribovskimi območji Slovenije izseljevanje na območju preučevanja ni potekalo intenzivno.

Po razvojno-tipološki členitvi podeželja v RS (Kovačič 2000) sodi občina Ribnica na Pohorju med podeželska območja zmernega praznjenja. V obdobju 1961-1991 je znašal indeks rasti prebivalstva $v$ naseljih širšega območja preučevanja 65 (podatki so nanašajo na naselja Lehen na Pohorju, Janževski vrh in Orlica v celoti, in ne le za del naselij - Zgornji Lehen na Pohorju, Zgornji Janževski vrh in Zgornja Orlica -, ki sodijo v občino Ribnica na Pohorju). Ker je bil naravni prirastek pozitiven, lahko sklepamo, da je bilo zmanjševanje števila prebivalcev posledica odseljevanja s tega območja. Najnovejši podatki kažejo, da se težnja po zmanjševanju prebivalstva nadaljuje: od začetka devetdesetih let do leta 2004 je bil selitveni saldo negativen, prav tako pa tudi naravni prirastek, kar je med drugim tudi posledica več desetletnega praznjenja, zlasti odhajanja mladega, vitalnega dela populacije. Ker je bilo v obdobju 1961-1991 manjše zmanjšanje prebivalstva zabeleženo le v manj agrarnih naseljih (Josipdol in Ribnica na Pohorju), lahko sklepamo, da je glede na obsežno agrarno zaledje depopulacija na območju preučevanja tesno povezana s kmečkim prebivalstvom.

Na kmetijskih gospodarstvih preučevanega območja se je v obdobju 1961-2001 (v nadaljevanju referenčno obdobje) zaradi odseljevanja število članov zmanjšalo skoraj za polovico, povprečni indeks odseljevanja znaša namreč 50,3. Po Hriberniku (1994) je socialne in ekonomske možnosti kmečkega prebivalstva zelo omejil z zakonom določen zemljiški maksimum iz leta 1953, kar je po Natku (1976) najprej najbolj prizadelo manjše zemljiške posestnike. Šele kasneje je nadaljnji razvoj neagrarnih dejavnosti, ki je za svojo nemoteno rast potreboval novo delovno moč, pričel z deagrarizacijskimi silnicami segati tudi po delovni sili na večjih kmetijah (Natek 1976, po Klemenčiču 1972, 60). Pozitivno povezanost med indeksom odseljevanja 2001/1961 in velikostjo kmetijskih gospodarstev ter statistično značilnost povezave lahko potrdimo tudi za kmetijska gospodarstva na preučevanem območju $(\mathrm{r}=0,858 ; \mathrm{p}=0,000)$, kar pomeni, da se je na večjih kmetijskih gospodarstvih odselilo manjše število ljudi, kakor na manjših kmetijah, kjer so bili učinki procesa deagrarizacije pogosto povezani s popolnim opuščanjem kmetijskih gospodarstev.

Kot enega od vzrokov za depopulacijo navaja Perko (1987) tudi nadmorsko višino, in sicer naj bi se z višanjem nadmorske višine depopulacija povečevala. Na območju preučevanja je povezanost med indeksom odseljevanja 2001/1961 in nadmorsko višino domov kmetijskih gospodarstev statistično pomembna in negativna $(r=-0,319 ; \mathrm{p}=0,001)$. Ker pa sta nadmorska višina in naklon kmetijskih zemljišč med seboj tesno povezana $(r=0,762 ; p=0,000 ; N=$ 119) in je z indeksom odseljevanja 2001/1961 povezan tudi naklon kmetijskih zemljišč (r $=-0,221 ; \mathrm{p}=0,027)$, smo s parcialno korelacijo ugotovili, da je imela nadmorska višina $\mathrm{v}$ referenčnem obdobju na odseljevanje prebivalstva večji vpliv kot naklon. Pokazalo se je še, da 
del vpliva nadmorske višine odpade na posredni vpliv prek oddaljenosti, saj se z nadmorsko višino povečuje tudi oddaljenost od centralnih naselij.

Za območje preučevanja smo povezanost $\mathrm{z}$ indeksom odseljevanja potrdili tudi za socioekonomsko strukturo kmetijskih gospodarstev, s katero ugotavljamo t. i. nepopolno deagrarizacijo - na mešanih kmetijskih gospodarstvih je povprečni indeks odseljevanja $2001 / 1961$ manjši kot na čistih $\left(M_{\text {mešane }}=60,0 ; M_{\text {čiste }}=53,8\right)$.

Ker sta po Hriberniku (1996) za socialno varnost kmečkega prebivalstva poleg posestne strukture pomembni tudi kvantiteta in zlasti kvaliteta človeških potencialov, se je s procesom deagrarizacije pojavil problem zagotavljanja ustrezne socialne varnosti na kmetijah, in sicer v dveh primerih:

(a) ko se je s kmetijskega gospodarstva odselilo preveliko število delovne moči oziroma je bilo odseljevanje hitrejše kot proces kmetijskega preusmerjanja in modernizacije;

(b) ko se je pričel s popolnim odseljevanjem mladih, predvsem tistih, ki so v izobraževalnem sistemu uspeli doseči višje izobrazbene dosežke, siromašiti delovni in umski potencial podeželja (Cunder 1998, Hribernik 1993a 1993b).

Ta pojav (a)je na območju preučevanja značilen zlasti za dopolnilna, ostarela in neaktivna kmetijska gospodarstva, ki so že leta 1961 imela manjše število članov kot je znašalo skupno povprečje, odselilo pa se več članov, kot je znašalo povprečje v referenčnem obdobju. Za razliko od čistih kmetij, na katerih je leta 2001 živelo 4,81 oseb, in za razliko od mešanih kmetij s 3,89 člani, je bilo na dopolnilnih kmetijah povprečno le 1,92 oseb, na ostarelih pa 1,22 oseb.

Slika 2: Deleži kmetijskih gospodarstev po številu družinskih članov v občini Ribnica na Pohorju. Figure 2: Share of farms according to number of family members in municipality Ribnica na Pohorju.

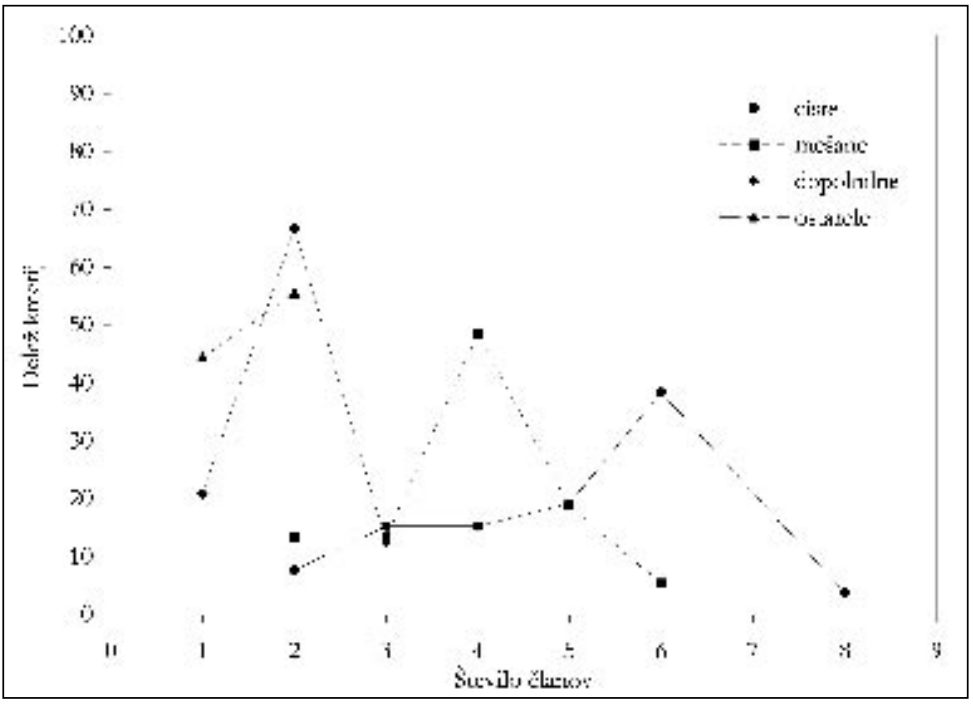


$\mathrm{K}$ b) Povprečna starost odseljenega populacijskega kontingenta na območju preučevanja je v referenčnem obdobju med 20 in 25 let $(\mathrm{M}=23,4$ leta), kar ustreza ugotovitvi, da deagrarizacija na nerazvitih območjih odteguje tamkajšnjemu kmetijstvu predvsem mlado prebivalstvo nad 20 let, ki se po večini odseli iz teh območij v urbane centre (Natek 1976, 60).

Slika 3: Ciljne destinacije odseljenih članov kmetijskih gospodarstev v obdobju 1961-2001v občini Ribnica na Pohorju.

Figure 3: Target destinations of emigrated members of farm households in the period 1961-2001 in the municipality Ribnica na Pohorju.

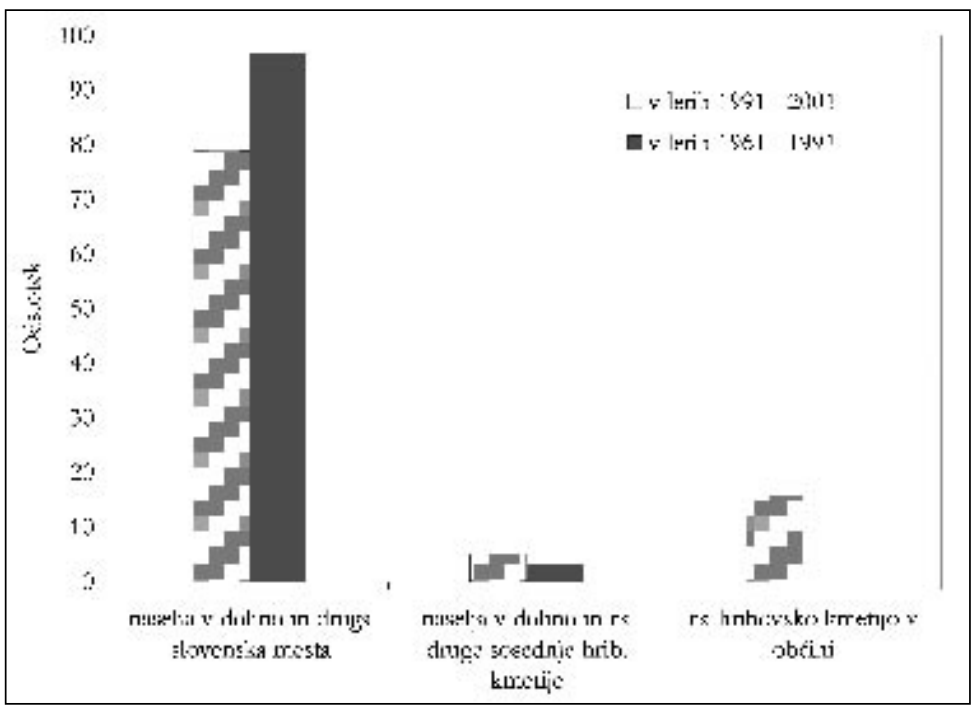

\subsection{Demografska vitalnost}

Čeprav sam proces deagrarizacije še ne pomeni, zmanjševanja obsega kmetijske dejavnosti, pa v specifičnih okoliščinah (npr. hribovitih območjih) običajno slabi demografska vitalnost podeželskega prebivalstva.

Za starostno strukturo kmetijskih gospodarstev ugotavljamo, da je na območju preučevanja zelo neugodna. Okoli $20 \%$ oseb je starejših od 64 let oziroma skoraj polovica (47 \%) je starih nad 50 let. V povprečju je na kmetijskem gospodarstvu 0,77 oseb v starosti 0-24 let, pri čemer ta starostni kontingent populacije odpade le na kmetije s čisto in z mešano socioekonomsko strukturo. Ugotovitev Hribernika (1996), da imajo kmečke ženske še vedno v povprečju večje število potomcev, za območje preučevanja drži le v primeru čistih kmetij, pri katerih na starostno skupino 0-24 let odpade 40 \% vseh članov. Ker pa je indeks odseljevanja 2001/1961 na čistih kmetijah nižji od indeksa odseljevanja mešanih kmetijskih gospodarstev, 
sklepamo, da se bo ob ohranitvi čiste socio-ekonomske strukture s kmetijskega gospodarstva odselil večji del teh članov. Dolgoročno imajo torej mešane kmetije na območju preučevanja ugodnejšo starostno strukturo prebivalstva. Čeprav t. i. delavsko-kmečke družine težijo k zmanjševanju števila otrok in imajo v primerjavi s čistimi kmetijami 46 \% manj članov v starosti 0-24 let, so po Kovačiču (1996) kmetije, ki kombinirajo vire dohodkov, vitalnejše. Samo kmetovanje namreč ne zagotavlja tako ugodne socialne varnosti kot kombinacija dohodka iz kmetijstva in zaposlitve (Kovačič 1996, 38). Navedena ugotovitev pa na območju preučevanja ne ustreza za dopolnilne kmetije, na katerih so sicer vsi aktivni delovni člani zaposleni ali prejemajo pokojnino oziroma so vzdrževani. Na podlagi visokega indeksa odseljevanja v referenčnem obdobju, ki znaša 38,1 in je le manj kot 4 indeksne točke nižji od indeksa odseljevanja ostarelih kmetij, sklepamo, da je na teh kmetijah poleg nepopolne prišlo tudi do popolne deagrarizacije, ki je v celoti devitalizirala demografski potencial kmetij. Po Hriberniku (1996) je zato nastala »medgeneracijska luknja«, zaradi česar ni zagotavljanja socialna varnost starejše generacije. Tudi povprečna starost članov kmetijskih gospodarstev z dopolnilno socio-ekonomsko strukturo se bolj približuje povprečni starosti članov ostarelih kmetij $\left(M_{\text {doponinine }}=61,3 ; M_{\text {ostarele }}=69,2\right)$ kakor povprečni starosti mešanih kmetij $(M=45,2)$. $\mathrm{Na}$ neugoden demografski potencial kmetijskih gospodarstev preučevanega območja opozarjajo tudi indeksi staranja. Na preučevanem območju znaša povprečen indeks staranja za kmetijska gospodarstva 145,5, in je torej višji, kot je po podatkih popisa leta 2000 znašal povprečni indeks staranja za vse člane kmetijskih gospodarstev v Sloveniji $(\mathrm{M}=135)$ oziroma višji, kot je bilo povprečje za vso prebivalstvo Slovenije leta $2002(\mathrm{M}=96,3)$. Po Hriberniku (1994) je zaradi pojava staranja kmečkega prebivalstva opazno tudi spreminjanje zunanje podobe podeželskega prostora. »Ta proces spremlja predvsem hribovska območja, na katerih se nekdanja obdelovalna zemljišča hitro zaraščajo« (Hribernik 1994, 27). Tudi na območju preučevanja t-test med prvo skupino kmetij s predvidenimi kmetijskimi zemljišči v zaraščanju in drugo skupino kmetij, na katerih respondenti ne predvidevajo, da se bodo kmetijska zemljišča v prihodnosti zaraščala, kaže, da se skupini pomembno razlikujeta po povprečni starosti članov na kmetijskem gospodarstvu $\left(\mathrm{M}_{1}=59,4 ; \mathrm{M}_{2}=43,5 ; \mathrm{t}(98)=5,02\right.$; $\mathrm{p}=0,000)$. $\mathrm{S}$ podrobnejšo analizo rezultatov smo ugotovili, da so razlike med skupinama statistično pomembne tudi glede na starost gospodarjev na kmetijskem gospodarstvu ( $\mathrm{t}(98)$ $=3,62 ; \mathrm{p}=0,000)$, pri čemer je povprečna starost gospodarjev na kmetijah s predvidenimi kmetijskimi zemljišči v zaraščanju je 63,5 let, na kmetijskih gospodarstvih, kjer se kmetijska zemljišča ne bodo zaraščala, pa 52,6 let.

Povprečna starost članov na kmetijskem gospodarstvu in starost gospodarjev na kmetijskem gospodarstvu pa ni edini »demografski« vzrok za zaraščanje kmetijskih zemljišč v prihodnosti. Ugotavljamo namreč, da živi na kmetijskih gospodarstvih, kjer se bodo v prihodnje zaraščala kmetijska zemljišča, povprečno 2,1 oseb, medtem ko je na kmetijah, kjer do zaraščanja kmetijskih zemljišč ne bo prišlo, 3,9 članov. Razlike med skupinama so statistično pomembne $(\mathrm{t}(98)=-6,15 ; \mathrm{p}=0,000)$. Z zmanjševanjem števila oseb na kmetijskem gospodarstvu se tudi povečuje delež kmetijskih zemljišč, ki se že zaraščajo. Pearsonov koeficient korelacije med številom oseb na kmetijskem gospodarstvu in razmerjem med kmetijskimi zemljišči, ki se zaraščajo, ter vsemi kmetijskimi zemljišči je namreč statistično pomemben in je negativen (r $=-0,256 ; \mathrm{p}=0,000)$. 
Slika 4. Starostna piramida populacije kmetijskih gospodarstev v občini Ribnica na Pohorju. Figure 4: Age pyramide of farm population in municipality Ribnica na Pohorju.

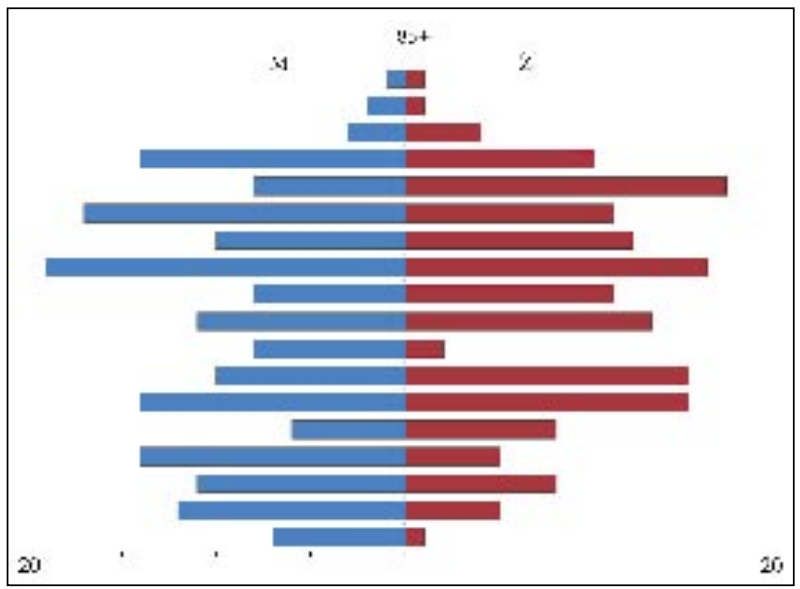

\subsection{Delovna storilnost}

Po popisu leta 2000 imajo slovenske kmetije povprečno 1,2 polnovrednih delovnih moči (PDM), vendar ta podatek ne kaže prave slike stanja, saj so med socio-ekonomskimi skupinami kmetij izrazite razlike (Kovačič 1996, 48).

Slika 5: Obseg delovne sile po socio-ekonomskih tipih kmetijskih gospodarstev vobčini Ribnica na Pohorju. Figure 5: Extent of labour force according to socio-economic farm types in municipality Ribnica na Pohorju.

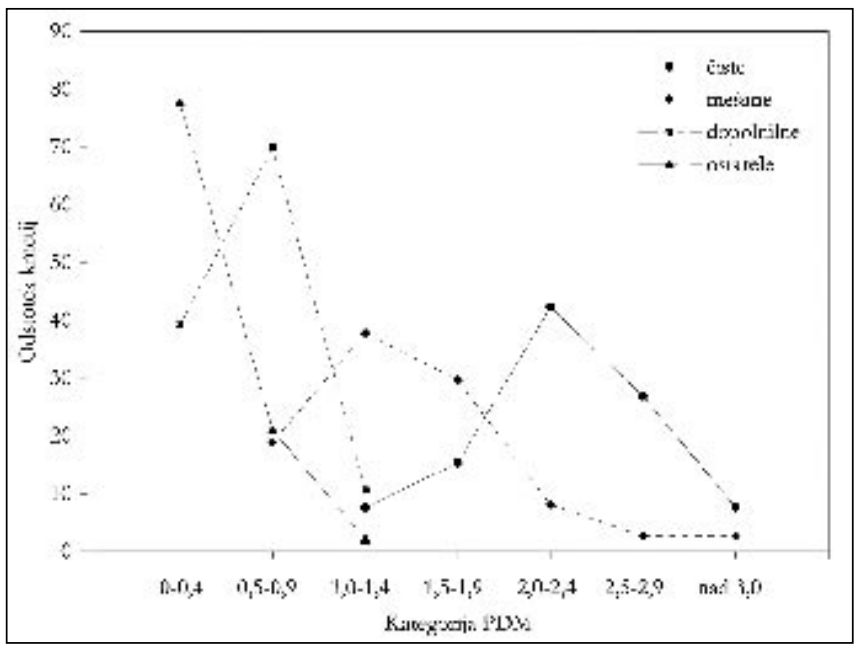


Razlik med skupinami zaradi neenakih varianc nismo preverjali $\mathrm{z}$ analizo variance, ampak s testom Kruskal-Wallis $\mathrm{H}$, ki kaže statistično pomembne razlike $\mathrm{v}$ vrednosti PDM-ja med posameznimi socio-ekonomskimi tipi $(\mathrm{H}(3)=63,13 ; \mathrm{p}=0,000)$. Kmetijska gospodarstva na območju preučevanja razpolagajo s 133,1 PDM-ja ( $\mathrm{M}=1,39 \mathrm{PDM} /$ enoto preučevanja). Višjo povprečno vrednost lahko razložimo z višjim deležem čistih kmetij na območju preučevanja, kot jih navaja Kovačič (1996) za Slovenijo leta 1991 in za leto 2000. Čiste kmetije v povprečju razpolagajo $\mathrm{z}$ več $\mathrm{PDM}$-ja kot kmetije $\mathrm{z}$ drugim socio-ekonomskim statusom. $\mathrm{Na}$ območju preučevanja imajo čiste kmetije povprečno 2,29 PDM-ja oziroma obsegajo skoraj polovico vseh PDM-jev, saj znaša povprečje za mešane kmetije 1,43 PDM-ja. Dopolnilne kmetije imajo povprečno 0,70 PDM-ja, ostarele pa 0,31 PDM-ja. Čeprav je dopolnilnih in ostarelih kmetij po številu enako kot mešanih ( $\mathrm{N}=37$ ), razpolagajo le s 15,6 \% vseh PDM-jev na območju preučevanja oziroma s 60,8 \% nižjo vrednostjo PDM-jev kot mešane kmetije.

Na območju preučevanja je kmetij z manj kot 1 PDM-jem 39,6 \%, kar je veliko, glede na to, da je povprečna vrednost PDM-jev tukaj višja kot v Sloveniji. Pomemben delež mešanih kmetij (19,1\%), katerih povprečen PDM je sicer višji od skupnega povprečja, ima namreč manj kot 1 PDM, dopolnilnih kmetij nad to mejo pa je le $10 \%$. Vendar je manjša vrednost PDM-ja z zmanjševanjem velikosti posesti, zlasti kmetijskih zemljǐ̌č, ki zahtevajo večjo delovno intenziteto, razumljiva in nujna. $Z$ razvojem tržnega kmetijstva se namreč po Vrišerju (1998) delovna storilnost povečuje $\mathrm{z}$ nadomeščanjem živega dela $\mathrm{z}$ opredmetenim.

Slika 6: Povprečni PDM/ha KZU-ja po socio-ekonomskih tipih kmetijskih gospodarstev v občini Ribnica na Pohorju.

Figure 6: Average AWU/hectar FLU according to socio-economic farm types in municipality Ribnica na Pohorju.

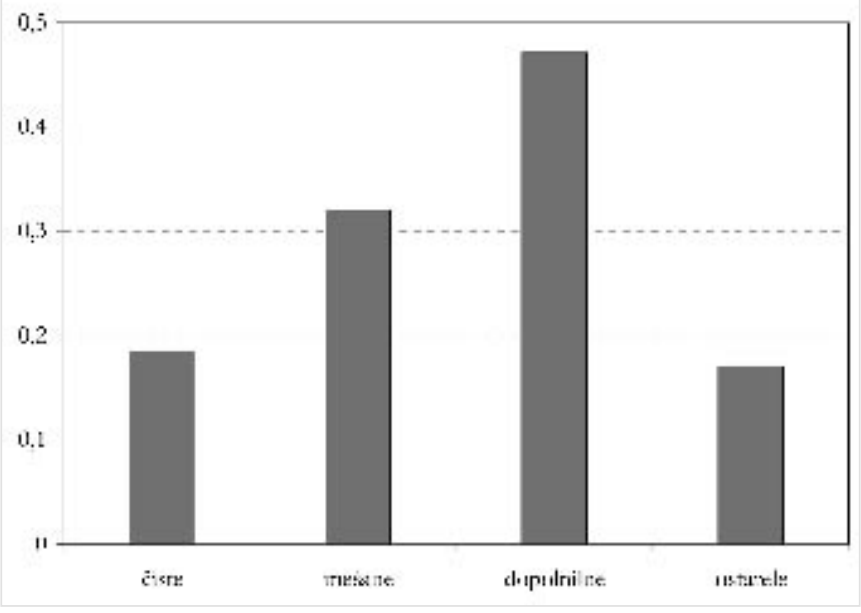

Po popisu 2000 pride na 1 PDM 4,5 ha kmetijskih zemljišč v uporabi (KZU) oziroma na 1 ha KZU 0,22 PDM-ja, kar kaže na nizko delovno storilnost slovenskega kmetijstva. Povprečna vrednost za kmetije na območju preučevanja znaša 0,29 PDM/ha KZU oziroma 
3,4 ha KZU na 1 PDM. Najnižja delovna storilnost je značilna za dopolnilne kmetije. Nizka vrednost PDM/ha KZU-ja pri ostarelih kmetijah sicer kaže na visoko delovno storilnost, vendar je to posledica oslabelih, devitaliziranih delovnih potencialov, ki imajo zaradi nizke stopnje aktivnosti na kmetijskem gospodarstvu tudi nizko vrednost PDM-ja.

Z dokazom statistično pomembnih razlik v vrednosti PDM/ha KZU-ja za posamezne socio-ekonomske tipe kmetijskih gospodarstev na območju preučevanja $\left(\mathrm{Me}: \mathrm{x}^{2}(3)=15,22\right.$; $\mathrm{p}=0,002)$ potrjujemo Cundrovo $(1997,155)$ ugotovitev, da se gledano z razvojnega vidika, v slovenskem kmetijstvu, s tem pa tudi v slovenskem kmetijskem prostoru, poglablja protislovnost med socialno-ekonomsko strukturo prebivalstva in zemljiško strukturo.

$\mathrm{Na}$ podlagi frekvenčne distribucije socio-ekonomskih tipov kmetijskih gospodarstev po velikostnih skupinah ugotavljamo, da obstajajo statistično pomembne razlike v vrednosti PDM/ ha KZU tudi med posameznimi velikostnimi skupinami kmetijskih gospodarstev (Me: $\mathrm{x}^{2}(3)$ $=34,80 ; \mathrm{p}=0,000)$. Ker med posameznimi socio-ekonomskimi tipi kmetijskih gospodarstev znotraj velikostnih skupin ni statistično pomembnih razlik, smo zato da bi ugotovili, katera izmed od obeh spremenljivko ima potencialno večji vpliv na vrednost PDM/ha KZU-ja (možnost je potencialna, ker bi morali izračunati linearno regresijo), izračunali korelaciji obeh spremenljivk s kriterijem $(\mathrm{r}=0,233 ; \mathrm{p}=0,000$ in Spearmanov koeficient $=0,577 ; \mathrm{p}=$ 0,000). Izračuni kažejo, da ima velikostna struktura kmetijskih gospodarstev pomembno večji vpliv na vrednost PDM/ha KZU-ja in s tem na delovno storilnost na kmetijskih gospodarstvih preučevanega območja kot pa socio-ekonomska struktura. Torej lahko za območje preučevanja potrdimo trditev, da z večanjem posesti narašča tudi produktivnost dela (Cunder 1997, 155).

\subsection{Nasledstvena kontinuiteta}

Kmečko prebivalstvo je edini del družbe, ki samo zagotavlja lastno socio-profesionalno reprodukcijo, zato je stanje nasledstva eden ključnih dejavnikov reproduktivne sposobnosti kmetije in s tem njenega dolgoročnega razvoja (Kovačič 1996, 82). Na območju preučevanja ima zagotovljenega naslednika $30 \%$ kmetij, vendar urejeno nasledstvo še ne pomeni, da bo kmetijsko gospodarstvo kot socio-proizvodna enota obstojalo tudi v prihodnosti. Za to mora biti izpolnjen temeljni pogoj, da bodo na kmetiji dejansko ostali predvideni nasledniki, ki bodo tudi nadaljevali s kmetovanjem. S tega vidika je delitev kmetijskih gospodarstev na tiste, ki imajo zagotovljeno nasledstveno kontinuiteto, in tista, ki nasledstvene kontinuitete nimajo zagotovljene, premalo natančna. Na območju preučevanja smo zato glede na nasledstveno vitalnost kmetijska gospodarstva razvrstili na nasledstveno vitalna, potencialno nasledstveno vitalna in nevitalna kmetijska gospodarstva, in sicer na podlagi predstavljenega algoritma.

Med nasledstveno vitalne kmetije sodi $30 \%$ enot, $31 \%$ kmetij sodi v skupino potencialno vitalnih kmetij, 39 \% kmetij pa v skupino z nevitalno nasledstveno strukturo. Potencialno vitalne kmetije in nasledstveno nevitalne kmetije obsegajo $37,1 \%$ vseh kmetijskih površin in 54,7 \% vseh članov kmetijskih gospodarstev na območju preučevanja. Zlasti za nevitalna kmetijska gospodarstva obstaja velika verjetnost, da se jim bo v prihodnje spremenila lastniška, posestna, demografska in proizvodna struktura, s tem pa se bo spremenila tudi socio-ekološka stabilnost in splošen videz kulturne pokrajine. 
Slika 7: Algoritem za določanja skupin nasledstvene vitalnosti kmetijskih gospodarstev

Figure 7: Algorithem for defining groups of farm succession vitality

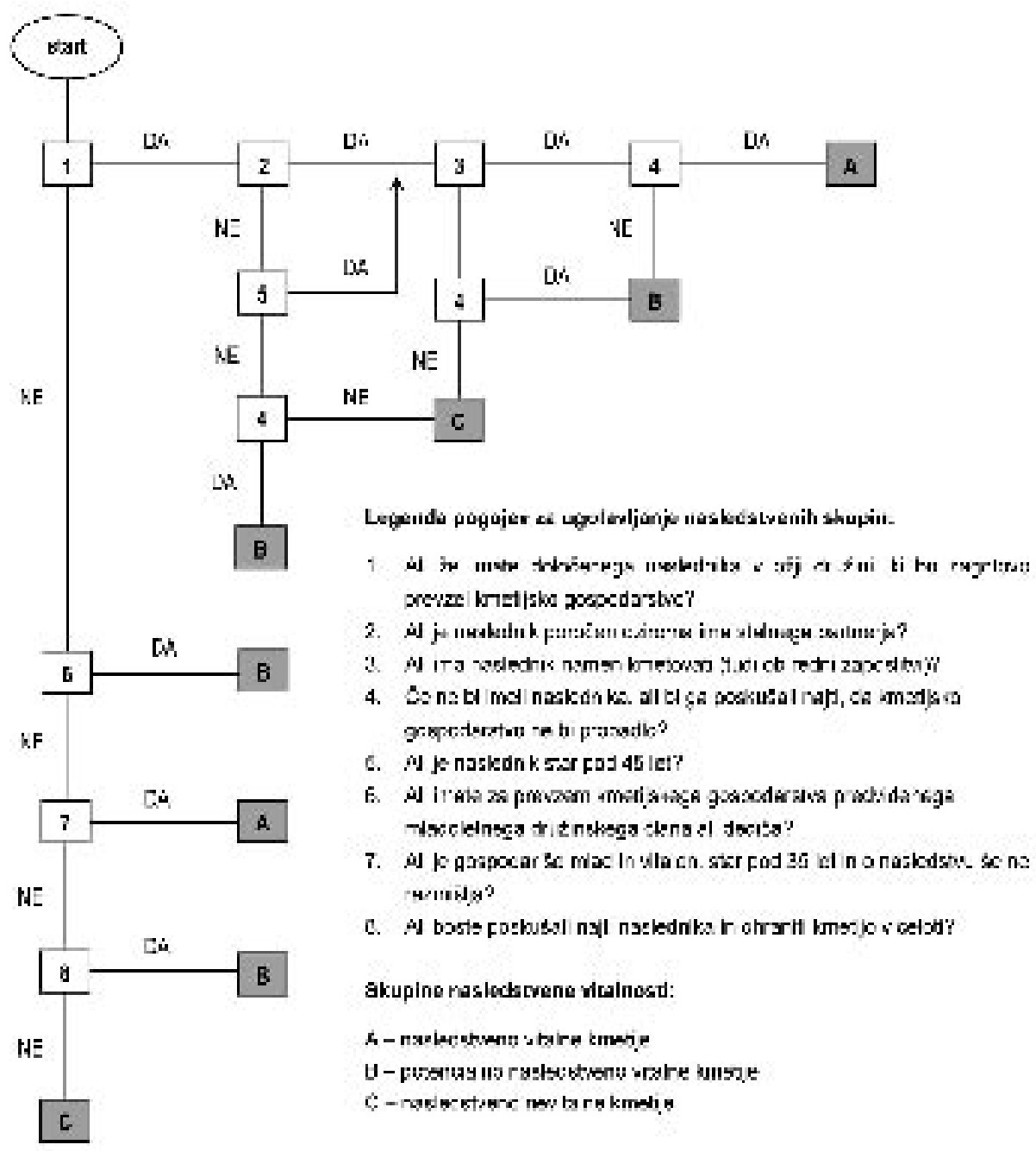

Socio-ekonomska struktura sicernima pomembnega vpliva na strukturonasledstvene vitalnosti, vendar je zanimivo, da vse ostarele kmetije v nasprotju s pričakovanjem niso nasledstveno nevitalne, glede na to, da naslednika še nimajo določenega oziroma predvidenega. Dokler namreč obstaja motivacija gospodarja za iskanje naslednika in ohranitev posestne celovitosti ter socio-proizvodne funkcije, kmetije ne moremo uvrstiti med nasledstveno nevitalne. 
Preglednica 1: Nasledstvena vitalnost kmetijskih gospodarstev po socio-ekonomski strukturi v občini Ribnica na Pohorju

Table 1: Succession vitality of farms according to socio-economic farm types in municipality Ribnica na Pohorju.

\begin{tabular}{|l|r|r|r|r|}
\hline & Čiste & Mešane & Dopolnilne & Ostarele \\
\hline Vitalne & 21 & 9 & & \\
\hline Potencialno vitalne & 5 & 11 & 11 & 4 \\
\hline Nevitalne & & 17 & 13 & 5 \\
\hline
\end{tabular}

Po drugi strani nekatere mešane in dopolnilne kmetije, ki sicer že imajo določenega naslednika, sodijo med nasledstveno nevitalne, saj nasledniki ne nameravajo kmetovati. Gre za kmetije, ki imajo tako kot vse druge nasledstveno nevitalne kmetije, v večini primerov nizko velikostno strukturo. Med nasledstvenimi skupinami namreč obstajajo statistično pomembne razlike v velikosti (ANOVA: $F(2 ; 97 ; 99)=23,5 ; \mathrm{p}=0,000)$ in sicer so vitalne kmetije v povprečju velike 52,3 ha, potencialno vitalne 26,5 ha in nasledstveno nevitalne 7,5 ha. Sklepamo lahko torej, da pomenijo mešane kmetije, zlasti manjše, vmesno fazo pri opuščanju kmetovanja.

\section{SKLEP}

Zahribovske kmetije na Dravskem Pohorju ugotavljamo, da imajo neugoden demografski potencial. Oslabljena je predvsem njihova demografska vitalnost, kar je posledica stalnega odseljevanja prebivalstva, predvsem s kmetij, ki so bolj oddaljene od centralnih naselij in so v višjih nadmorskih višinah. Ker se odseljujejo po večini mladi, je značilno nadpovprečno staranje prebivalstva, s tem pojavom pa je tesno povezano tudi zaraščanje kmetijskih zemljišč. $\mathrm{Z}$ odhajanjem mladih slabi tudi umski potencial hribovskih kmetij. Kmetje spodbujajo $\mathrm{k}$ doseganju višje stopnje izobrazbe predvsem tiste otroke, ki jih nimajo predvidenih za naslednike. Na kmetijah ostajajo po večini tisti, ki so v izobraževalnem procesu dosegli nižjo stopnjo izobrazbe. Gospodarji jih z odraščanjem vedno bolj vključujejo v delo na kmetiji, na njih postopoma prenašajo vedno več odgovornosti, s tem pa jih tudi v marsikaterem primeru ovirajo in celo onemogočajo, da bi se izobraževali. To pomeni, da je na hribovskih kmetijah na Dravskem Pohorju ob že tako neugodni nasledstveni vitalnosti oslabljena tudi kvaliteta demografskega potenciala.

\section{Viri in literatura}

Cunder, T., 1997. Naravne danosti in socio-ekonomska struktura. V: Slovensko kmetijstvo in Evropska unija : študija v okviru raziskovalnega projekta CRP Zemlja: Učinki vključevanja Slovenije v mednarodne integracije na slovensko kmetijstvo. Ljubljana, ČZD Kmečki glas, str. 143-155. 
Cunder, T., 1998. Kmetijstvo in ohranjanje poseljenosti v Sloveniji. V: Kmetijstvo in okolje : zbornik posveta, Bled, 12.-13.3. 1998. Ljubljana, Kmetijski inštitut, str. 37-47.

Hribernik, F., 1993a. Vloga izobraževanja v razvoju kmetijstva. Sodobno kmetijstvo, 26, 11, str. 458-462.

Hribernik, F., 1993b. Ali se je izobraženost kmečkega prebivalstva v zadnjem desetletju spremenila? Sodobno kmetijstvo, 26, 2, str. 61-67.

Hribernik, F., 1994. Proces zapuščanja kmetijstva se nadaljuje. IB revija, 28, 3-4, str. 26-34.

Hribernik, F., 1996. Ali lahko kmetije v Sloveniji zagotavljajo primerno socialno varnost kmečkemu prebivalstvu? Socialno delo, 35, 1, str. 15-30.

Kovačič, M., 1983. Tipi kmetij v Sloveniji in njihove značilnosti. Raziskave in študije, 63, str. 5-73.

Klemenčič, V., 1972, Geografija prebivalstva Slovenije, Geografski vestnik, 44, str.133-142

Kovačič, M., 1996. Socio-ekonomska in velikostna struktura kmetij v Sloveniji v obdobju 1981-1991. 1. izd. Ljubljana, Biotehniška fakulteta, Oddelek za agronomijo in Inštitut za agrarno ekonomiko, 104 str.

Kovačič, M., 1997. Obseg profesionalizacije kmetijstva. V: Zasnova strategije in metodološke osnove celovitega razvoja in urejanja podeželja. Ljubljana, Ministrstvo za znanost in tehnologijo, Ministrstvo za kmetijstvo, gozdarstvo in prehrano, str. 69.

Kovačič, M., 2000. Razvojno-tipološka členitev podeželja v Republiki Sloveniji. 1. izd. Ljubljana, Biotehniška fakulteta, Oddelek za agronomijo, Inštitut za agrarno ekonomiko, 129 str.

Natek, M., 1976. Kmetijsko prebivalstvo v SR Sloveniji glede na zemljiško-posestne skupine. Geografski vestnik, 48, str. 57-76.

Natek, M., 1989. Kmetije kot činitelji in jedra gospodarske in socialne preobrazbe hribovskega sveta. V: Geografija in aktualna vprašanja prostorskega razvoja. Ljubljana, Filozofska fakulteta, Oddelek za geografijo. (Dela, 6, str. 196-207)

Perko, D., 1987. Nadmorska višina in odmiranje prebivalstva. V: Notranjska : zbornik 14. zborovanja slovenskih geografov, Postojna 15.-17. 10 1987. Ljubljana, ZGDS, str. 347-354.

Udovč, A., Kovačič, M., Kramarič, F., 2006. Socio-ekonomski tipi kmetij po podatkih popisa kmetijskih gospodarstev leta 2000. V: Slovenija v EU-izzivi za kmetijstvo, živilstvo in podeželje, 3. konferenca DAES, Moravske Toplice 10.-11. november 2005. Domžale, Društvo agrarnih ekonomistov Slovenije.

Vrišer, I., 1998. Uvod v geografijo. 6. izd. Ljubljana, Filozofska fakulteta, Oddelek za geografijo, 458 str.

Zgonik, M., 1977. Dravska dolina : novejši razvoj kulturne pokrajine. 1. izd. Maribor, Založba Obzorja, 368 str. 


\section{DEMOGRAPHIC POTENTIAL OF MOUNTAIN FARMS ON DRAVSKO POHORJE}

\section{Summary}

Demographic potential of mountain farms on Dravsko Pohorje is very unfavourable. Due to permanent emigration demographic vitality of farms is weakened, especially of those, which are remoted of central settlements and located on higher heights above sea level. Since mostly young people emigrate, aging of population is above average and overgrowing of agricultural land is closely linked to that phenomena. Owing to emigration of young population with higher degree of education, the intellectual potential is diminished as well. Children who are not designated to succeed the farms are more often stimulated to achieve higher degree of education by their parents as successors are, thus successors have lower degree of education. As they are growing up householders gradually incorporate them into labour on farms and transfer to them greater responsibilities, for that reason many successors do not have possibilities for further education. Consequently the quality of demographic potential of mountain farms on Dravsko Pohorje is weaker. 